\title{
Two cases of 16th century head injuries managed in royal European families
}

\author{
Kamilah A. Dowling, DNP,1,2 and James Tait Goodrich, MD, PhD, DSci² \\ 1Division of Pediatric Neurological Surgery and 'Leo Davidoff Department of Neurological Surgery, Albert Einstein College of \\ Medicine, Children's Hospital at Montefiore, Bronx, New York

\begin{abstract}
In Europe, during the 16th century, there were a number of prominent general surgeons adventurous enough to consider operating on the brain for head injuries. From the time of Hippocrates, operating on the skull and brain was considered both treacherous and too dangerous to be undertaken except on rare occasions. Operating on a member of a royal court was considered even more exceptional because if the outcome was poor, the surgeon could lose a hand or limb, or, even worse, be beheaded. The authors present two interesting cases of royal family members who underwent surgery for head injuries that were quite severe. The surgeons involved, Ambroise Paré, Andreas Vesalius, and Berengario da Carpi, were among the most prominent surgeons in Europe. Despite very challenging political situations, all were willing to undertake a complex surgical intervention on the member of a prominent royal family. The individuals involved, both royal and medical, plus the neurosurgical injuries are discussed.
\end{abstract}

http://thejns.org/doi/abs/10.3171/2016.4.FOCUS15119

KEY WORDS Ambroise Paré; Andreas Vesalius; Berengario da Carpi; Henry II; Lorenzo de Medici; head injury; traumatic injury; history of neurosurgery

$\mathrm{T}$ HE practice of surgery in 16th century Europe was undergoing changes of major proportions. For the first time, surgeons were developing a practice with the training and background of a university education. Prior to this, an individual with no formal education would learn his craft as an apprentice to an older, trained surgeon, otherwise known as a barber-surgeon. For a surgeon in the 16th century, the ability to desensitize patients from pain, i.e., anesthesia, was nonexistent, and what was available for the patient was primitive at best. Typically, what the surgeon could offer was mostly narcotics such as opium along with alcohol, and if necessary, the patient would be held down with heavy physical restraints during surgical procedures. Antisepsis was not at all appreciated, so blood-stained and dirty surgical instruments and clothing were commonly reused in surgeries.

The understanding of human anatomy was primitive and based mostly on Galenic teachings, which were more than 1300 years old. With the dawn of the Renaissance, a remarkable change was to occur in both medicine and sur- gery. Michelangelo and Leonardo da Vinci, among other important Renaissance artists, brought about this change with their brilliant anatomical dissections. ${ }^{10}$ Prior to this era, "anatomists" would read from books on the anatomy of man, and unfortunately these readings included many anatomical errors carried over from ancient animal studies dating back to the 2nd century AD. The artistic community was not restricted by these errors; rather, they were performing dissections to learn human surface anatomy and the underlying musculature. There was, however, a small group of talented physicians and surgeons undertaking great efforts to change these dissections to hands-on anatomy in which the physician/anatomist actually performed his own dissections. This was an extraordinary change in thought as the anatomy books from antiquity no longer ruled in the dissection theater; rather, it was the anatomist's hands-on findings that were now detailed. Due to the strong influences from the medieval teachings, there was extraordinary resistance to the "new," but clearly more accurate, anatomical findings. Added to this new develop- 
ment was the continual warfare in the form of military and political battles going on throughout the European continent. These conflicts provided the local military surgeons with a large supply of patients to work on, both surgically and anatomically. The injuries sustained during these wars necessitated more accomplished military surgeons who were able to develop vast and quite varied practices. One cannot underestimate the skills and experiences that developed because of these wars. Man has long known that, to defeat one's enemy, a blow to the head was clearly the best and most effective way to bring him down. In addition, the weapons and increasing use of gunpowder led to more severe head injuries. These more complex injuries forced surgeons to develop techniques to treat and revive the severely injured.

With this background, the purpose of this paper is to review two interesting 16th century head injuries that occurred in members of royal families. The surgeons involved in the treatment of these injuries, Ambroise Paré (1510-1590), Andreas Vesalius (1514-1564), and Jacopo Berengario da Carpi (1460-1530?), were among the most prominent surgeons in practice in Europe at this time. The patients they treated were members of high royal courts in Europe, and they included Henry II of France (1519-1559) and Lorenzo de Medici, Duke of Urbino (1492-1519) of Italy. Both of these individuals sustained serious head injuries and here, we review the contemporary surgical management and their outcomes after neurosurgical management. The impact of these injuries also influenced political outcomes in governments throughout Europe, which only continued to contribute to the political turmoil of the period.

\section{Berengario da Carpi and the Duke of Urbino: A Noble Head Injury by Arquebus Shot to the Head}

Jacopo Berengario da Carpi (aka Giacomo Barigazzi) (1460-1530?) was a polymath, anatomist, and surgeon. He was the son of a barber-surgeon who went on to receive his medical degree in 1489 from the University of Bologna. Upon completing his education, he had a distinguished and accomplished career both as an anatomist and surgeon. In 1502 , he was appointed lecturer in surgery in Bologna, one of "four foreign individuals," which was a rare honor. As part of the appointment, he was given an "eminenti" title. A significant moment in Berengario's career was to occur when he was asked to consult on a prominent political figure, Lorenzo de Medici, the Duke of Urbino (1492-1519). Berengario cared for Lorenzo in 1517 after the latter had sustained a severe head injury (Figs. 1 and 2).

Before reviewing the case study of Lorenzo de Medici, it is relevant to explore Berengario's background and why he remains a significant figure in the history of surgery and neurosurgery. For neurosurgeons, it is important to note that he is remembered for the first printed textbook devoted solely to the management and treatment of head injuries. ${ }^{1,11,14}$ In the first line of the preface to his book on head injuries, Berengario noted that he had just returned to Bologna, after “...the Most Illustrious Duke of Urbino had recovered from his injury, nothing was more pleasant

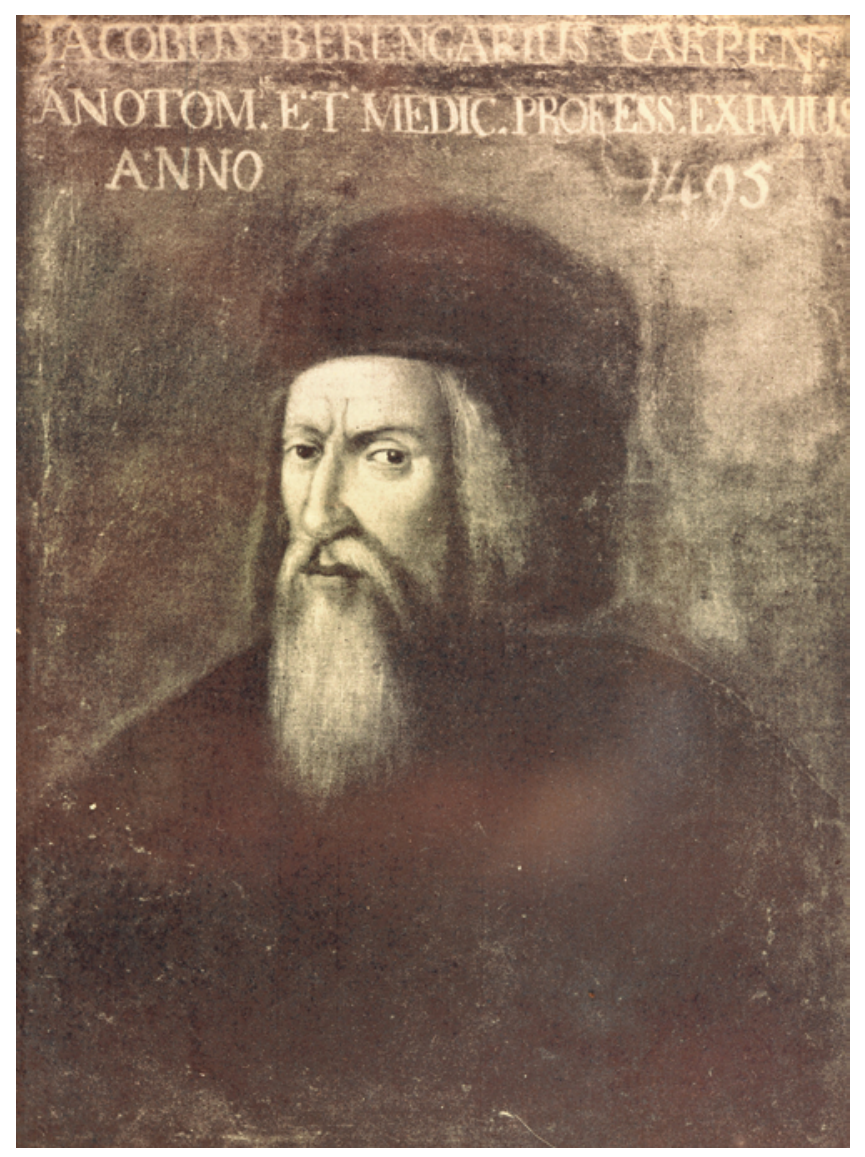

FIG. 1. An oil portrait of Berengario dated 1495 by an unknown artist. From the Civic Museum in Carpi, Italy. Photograph taken of portrait by author (J.T.G.) ca. 1972. The portrait was severely damaged in a recent earthquake that affected regions of Bologna and Carpi.

than to meet with scholars who for reasons were very close friends of mine. When I had come to them, they asked me about his condition, and after much had been said back and forth about surgery on the head, that day was completely gone." At the end of the day Berengario was tired and went to sleep. He then recounted a dream he had that night in which appeared the third Mercury (Hermes Trismegistus) who urged him to write this monograph on head injuries, as he was the best and the most skilled to do this. Berengario wrote in his introduction: ${ }^{1,11}$

In my dream there appeared a man wearing a cap adorned with a rooster feather and golden winged sandals, bearing in his hand a golden staff with a serpent wound about it. From that form he was known to me as the third Mercury (Hermes Trismegistus). I know that the plumed cap, winged sandals, and golden staff and serpent are proper for a physician. The ancients regarded a man of such appearance as the greatest physician. Therefore I approached him fearfully. But he said, "Forget your fear and lend me your ears for a while. How often, when they have asked you, have you promised your scholar friends a treatise on fracture of the skull? But until now you have not done this. ... So keep your promises, for they say you're a keeper of promises. If not, requests often turn into complaint, and even a beggar gets what he wants by an outcry." 1,11 


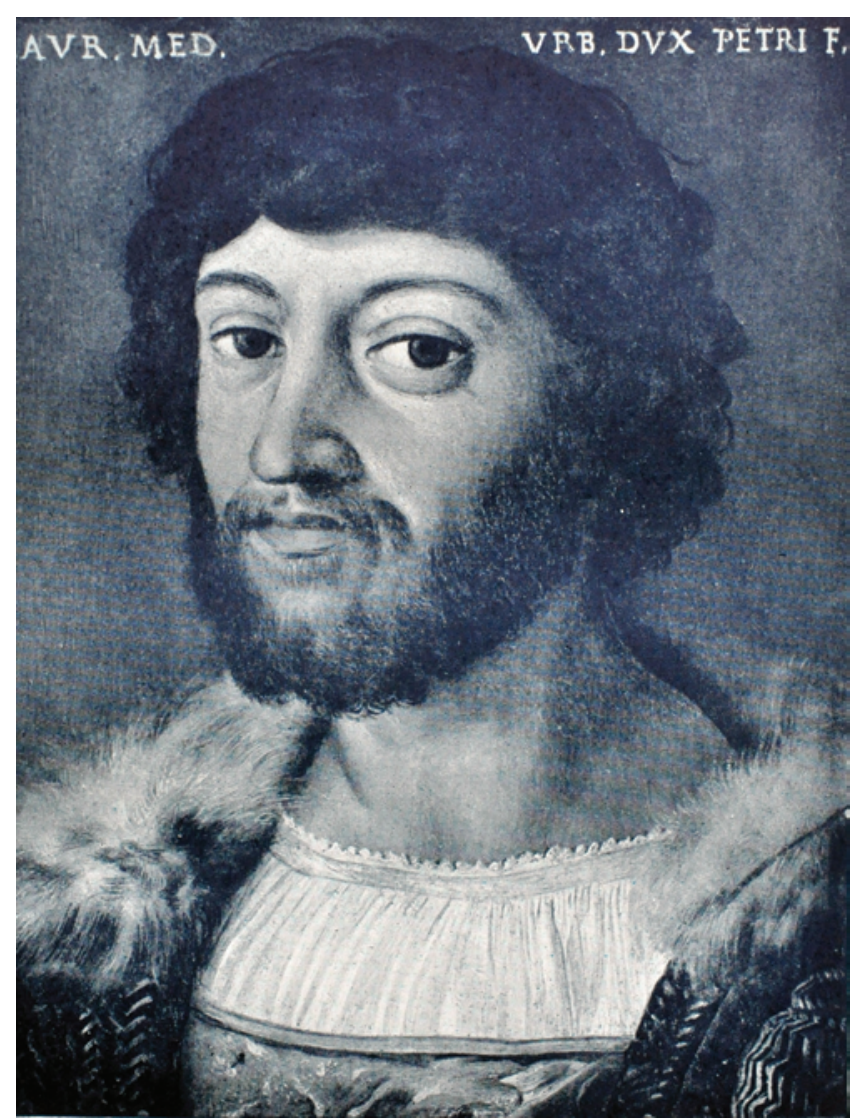

FIG. 2. An oil portrait of Lorenzo de Medici, from the Uffizi Gallery, Florence, Italy, photographed by the author (J.T.G.).

Berengario then noted that it was because of the urging of his "Duke" (of Urbino) that he went on to write this book. For those with knowledge of the Greek classics, it is of note that the "dream" Berengario created is a paraphrase of Scipio's Dream from Cicero's De Republica, which in part reuses full sentences and phrases. ${ }^{5,6}$ It is also interesting to note that no copies of De Republica were in existence until a palimpsest copy was discovered in 1819 in the Vatican library (Vat Lat 5757) by Cardinal Angelo Mai. This led to the question of what work Berengario was using; perhaps a copy now lost? There is also a copy of Scipio's Dream in a Middle Age manuscript by Macrobius, which might also be a possible source.

It is interesting to look back on Berengario, as he was an individual and surgeon with a remarkably aggressive and combative behavior. Contemporary colleagues described him as an individual who was argumentative, and, if provoked, his behavior could also become violent and destructive. ${ }^{8,11,19}$ In performing this historical review, bizarre episodes illustrating this behavior have been recorded. One of the more bizarre cases was when Berengario was alleged to have attacked and robbed a stipendiary of Pope Julius II in 1511 over a personal feud. An even more bizarre situation was reported in which Berengario physically attacked a local physician over his care of a mutual patient. This situation was provoked over patient management where Berengario clearly had differing views as to care. Berengario is also reported to have developed such severe anger over a prominent local patrician by the name of Zambelli Patenghi that he went on to attack and set fire to his home. ${ }^{11}$ In all of these situations, Berengario's reputation was so powerful in the local community that he was never punished. Part of his lack of punishment was likely due to the fact that he was physician and advisor to the Pontificate of Julius II and also Pope Leo X, a Medici. In his years of practice, the Medici family employed him as counsel and in turn repaid him well with both patronage and protection.

Lorenzo de Medici (1492-1519) was the ruler of the Florence Republic from 1514 through 1519 . He was the Duke of Urbino from 1516 to 1519 , a title given to him by Pope Leo X. He was also the illegitimate son of Alessandro de Medici and grandson of Lorenzo the Magnificent, a family lineage that was both remarkable and powerful. Lorenzo was father to Catherine de Medici (1519-1589) who later became a prominent and powerful figure in European politics. Catherine was to become Queen (Regent) of France, reigning from 1547 through 1559. Her husband was Henry II who would became King of France. Catherine married Henry II at the age of 14 and had 3 sons, who all achieved royal status. At this time, Europe was in a period of constant warfare involving both religious and civil wars and in turn supplied a good deal of injuries to surgeons.

Germane to this paper was the Civil War of Urbino, which occurred in 1517. Lorenzo was involved politically and became an active participant in the battles. While serving as a commander in this civil war, Lorenzo de Medici was wounded by an arquebus shot to the head. This injury resulted in a severe and complex depressed occipital skull fracture over the left transverse sinus. Lorenzo was initially treated in the field by a local military surgeon who performed a trephination over the occipital skull fracture. In retrospect, this was a rather adventurous procedure for the time, as the fracture was directly over a major venous sinus. In reviewing the records that are still available, there was apparently no direct injury to the vascular sinus from either the blow to the head or the surgery. ${ }^{8}$ After leaving the battlefield, his surgical care was turned over to Berengario da Carpi. Berengario consulted on this member of a royal family and reviewed the care delivered in the surgical field. Berengario told the patient that the use of trepan should not have been done, but did not elaborate why. Fortunately, Lorenzo went on to survive this traumatic brain injury and ended up retiring in Tuscany, only to die later of complications from the disorders of syphilis and tuberculosis. It is of interest to review the skull injury in more detail (Figs. 3 and 4).

In reviewing Lorenzo's skull injury, the fracture occurred in the left occipital region, which resulted in multiple pieces of skull bone being displaced. Additionally, it appears that the local field surgeon performed local debridement, only to stop when he likely saw the underlying transverse sinus. Berengario then had to remove more bone fragments and then apply local medications (to prevent infection?) to help cure the patient. A plaster casting of the skull from Lorenzo exists and is part of the Museum of the Institute of Anatomy (Florence, Italy). In examining 

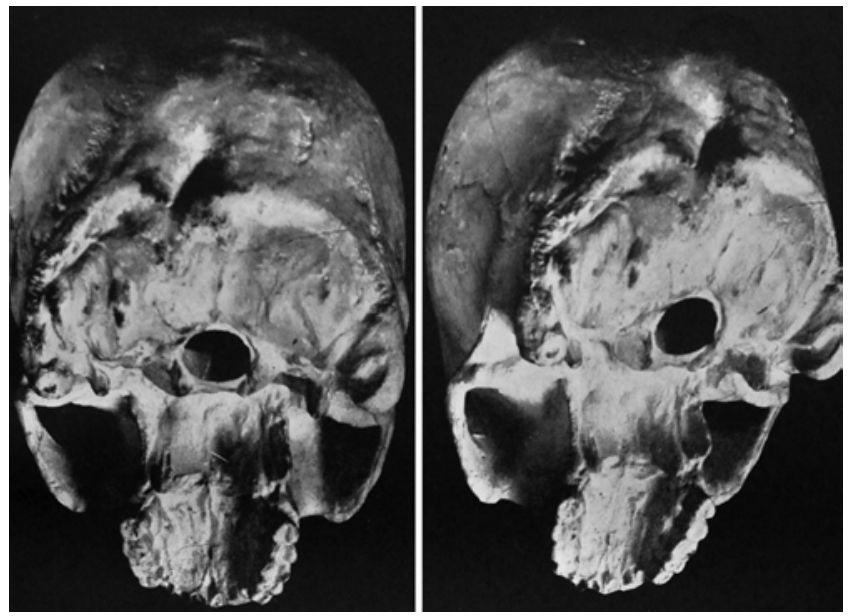

FIG. 3. Photographs of plaster casts of Lorenzo's skull showing the injury in the left occipital region that Lorenzo sustained as a result of the musket ball. It appears to have been a trajectory blow in which the missile transverses the skull rather than causing a direct penetration into the brain. Photographs taken by the author (J.T.G.). From the Museum of the Institute of Anatomy, Florence, Italy.

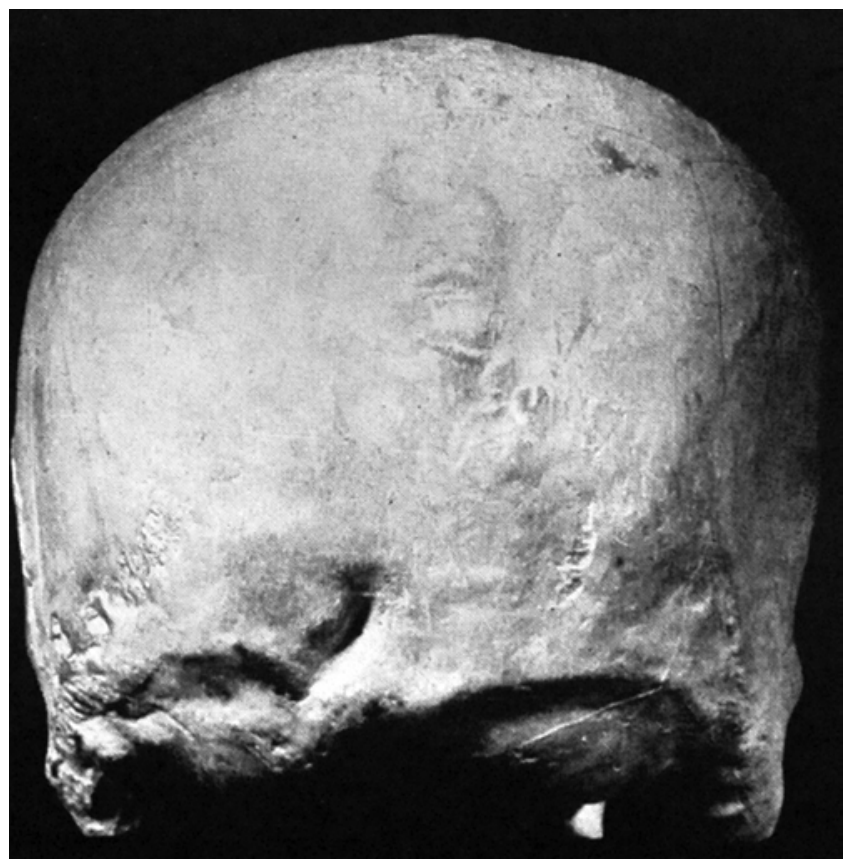

FIG. 4. The skull injury shows the healed bone over the injury site with no evidence of any osteomyelitis. Photograph taken by the author (J.T.G.). From the Museum of the Institute of Anatomy, Florence, Italy.

the area of the skull injury, one finds excellent bone healing with the linear groove still clearly seen in the skull. It is clear now that Berengario likely improved the outcome of Lorenzo. From his treatment, the local royalty considered him to be the savior of the Duke (Fig. 5).

Berengario da Carpi went on to develop an extraordinary career as both an anatomist and surgeon. His anatomical books have become classics, and his illustrations on human anatomical structures are now considered to be

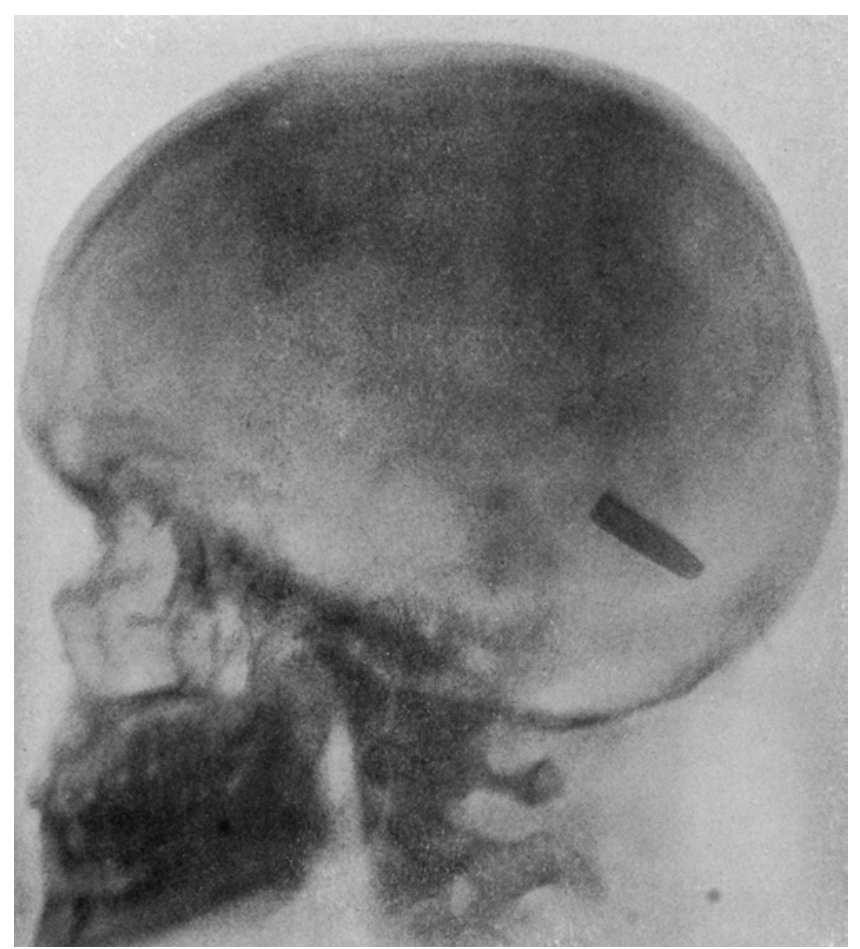

FIG. 5. An old skull radiograph dating from 1901 showing a military bullet (from a Mauser rifle) injury in the occipital region. The gunshot injury illustrated here is much like the one that occurred in Lorenzo from a musket ball. In this case the bullet went through (or at least very close to) the sinus and remained in the subcutaneous tissue. Original source: Park R: Injuries and surgical diseases of the head, in Park R (ed): A Treatise on Surgery by American Authors, for Students and Practitioners of Surgery and Medicine, ed 3. New York: Lea Brothers, 1901.

among the first to illustrate "realistic" human anatomy. For the first time since Galen of Pergamon, an anatomist would describe anatomical findings based on personal observations at cadaveric dissections. ${ }^{1-3}$ Berengario noted in the preface to the Isagoges that he had dissected "hundreds" of human bodies. Berengario began his anatomical treatise with the exclamation that anatomists should do their own dissections and describe what they actually see and not just repeat earlier anatomical findings that are in error from Galen of Pergamon, among others. In the title page to this anatomical book, Berengario provided a plate showing an anatomical dissection scene. This illustration is important since Berengario is the one holding the probe and directing the dissection. Berengario also wrote a commentary on Mondinus in 1514 and later in 1521, publications that still reflected many of the medieval teachings in medicine, yet again he argued for anatomists and physicians to only do hands-on studies and reflect in writing their personal observations (Figs. 6-8)., ${ }^{1,2}$

It is interesting to go back and perform a further review of Berengario's monograph on head injuries: De Fractura Calvae sive Cranei (Bologna, 1518), ${ }^{4,11}$ In addition to describing how to manage a head injury, there is also a step-by-step approach on how to do a trephination on the human skull. Not mentioned earlier, but interesting to note, is that Berengario dedicated this book to Lorenzo de Medici, the Duke of Urbino, his patient. The book is 


\section{ânatomia Carplo}

\section{-ISAGOGE BREVES}

\author{
Perlucide ac uberime, in Anatomiam hus: \\ mani corporis, a, cómuni Medicorum \\ Academia, ufitatam, a, Carpo in $\mathrm{Al}$. \\ mo Bononienfi Gymnafio Ordi \\ nariam Chirurgix publicx \\ Docente, ad fuorum \\ Scholafticorum \\ preces in lucê. \\ date:
}

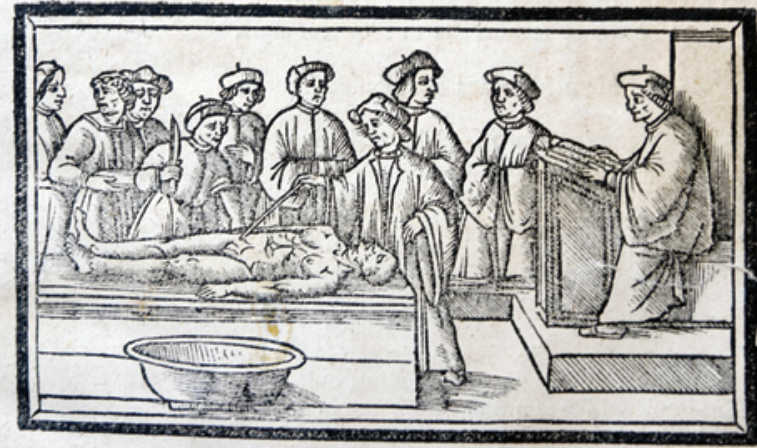

\section{VENETIIS ANNO .D. M.CCCCC.XXXV.}

FIG. 6. Title page from one of the editions of Berengario's anatomy book of the human body. The drawing depicts Berengario performing a dissection. Original source: Berengario da Carpi J: Isagoge breves, perlucide ac uberime in anatomia humani corporis a communi medicorum academia usitatam. Bologna: Benedicitum Hectoris, 1522.

\section{Eractatus oe Fractura Ealue fiue LranciaLarpoeditus,}

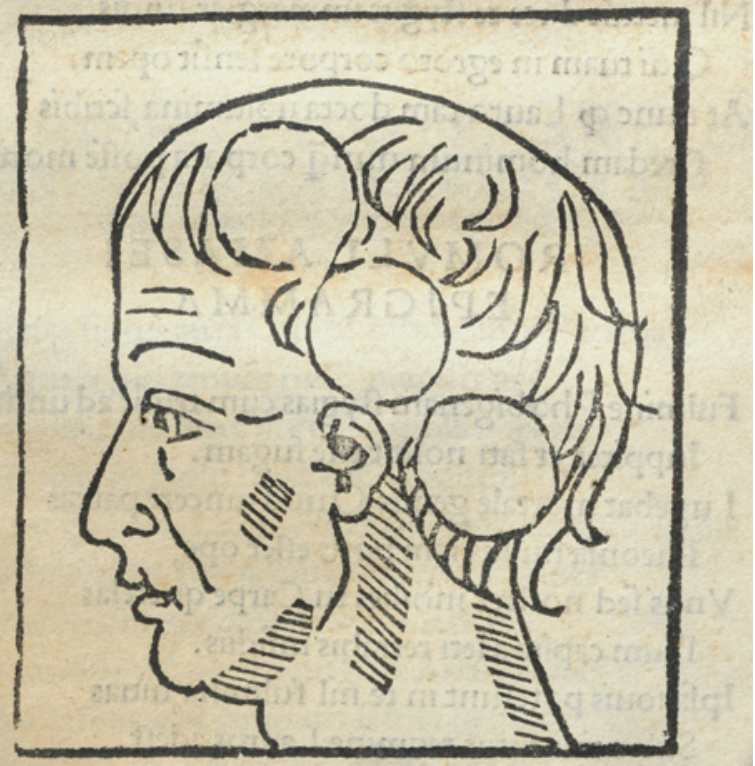

FIG. 8. An engraving from the title page of Berengario's treatise on the treatment of injuries to the head and skull. The image shown is interesting as it illustrates the ventricle system as represented in the "cell doctrine" theory in which the concepts of imagination, recognition, and cognition are functions that reside within the ventricles and not in the brain itself. Original source: Berengario da Carpi J: Tractatus de fractura calve sive cranei. Bologna: Hieronymus de Benedictis, 1518.
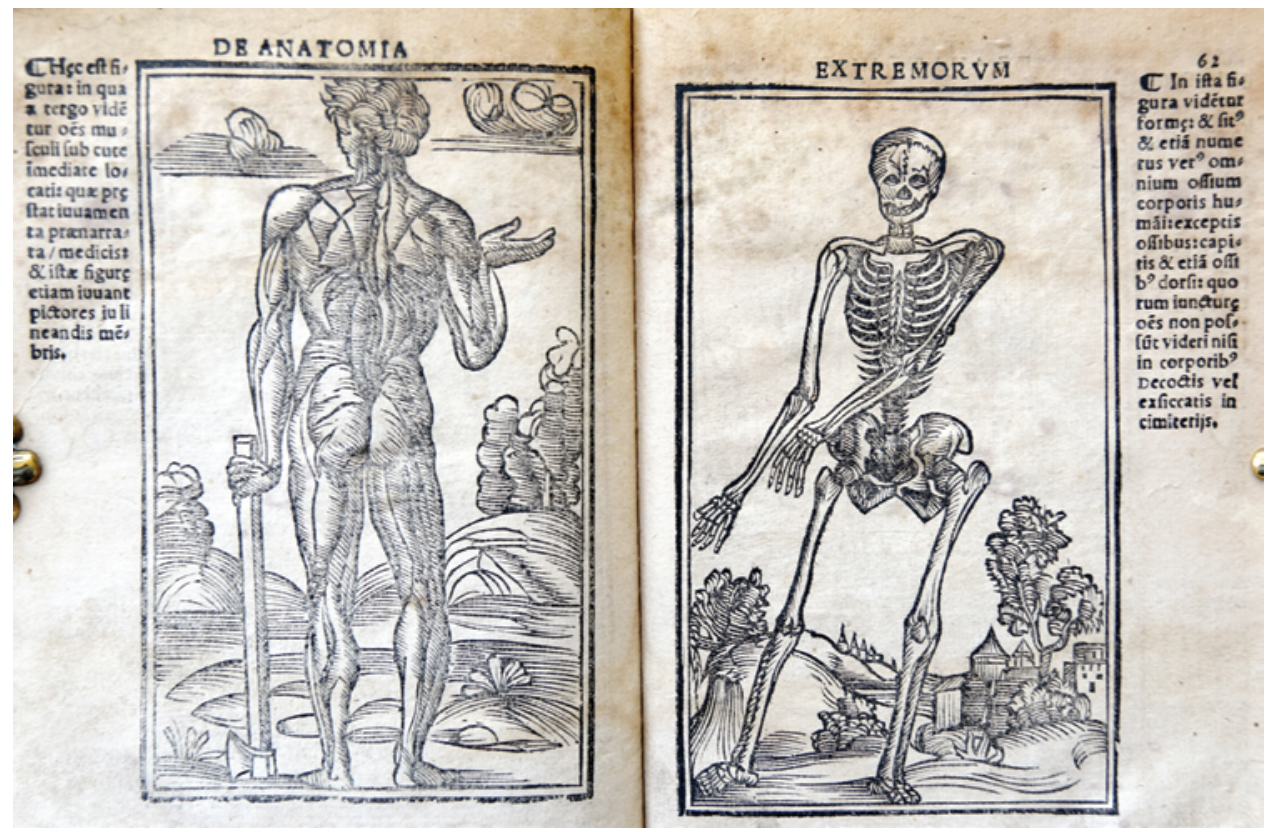

FIG. 7. Drawings of anatomical dissection from Berengario's book showing the illustration of a "muscle man" and a "human skeleton." Original source: Berengario da Carpi J: Isagoge breves, perlucide ac uberime in anatomia humani corporis a communi medicorum academia usitatam. Bologna: Benedicitum Hectoris, 1522. 


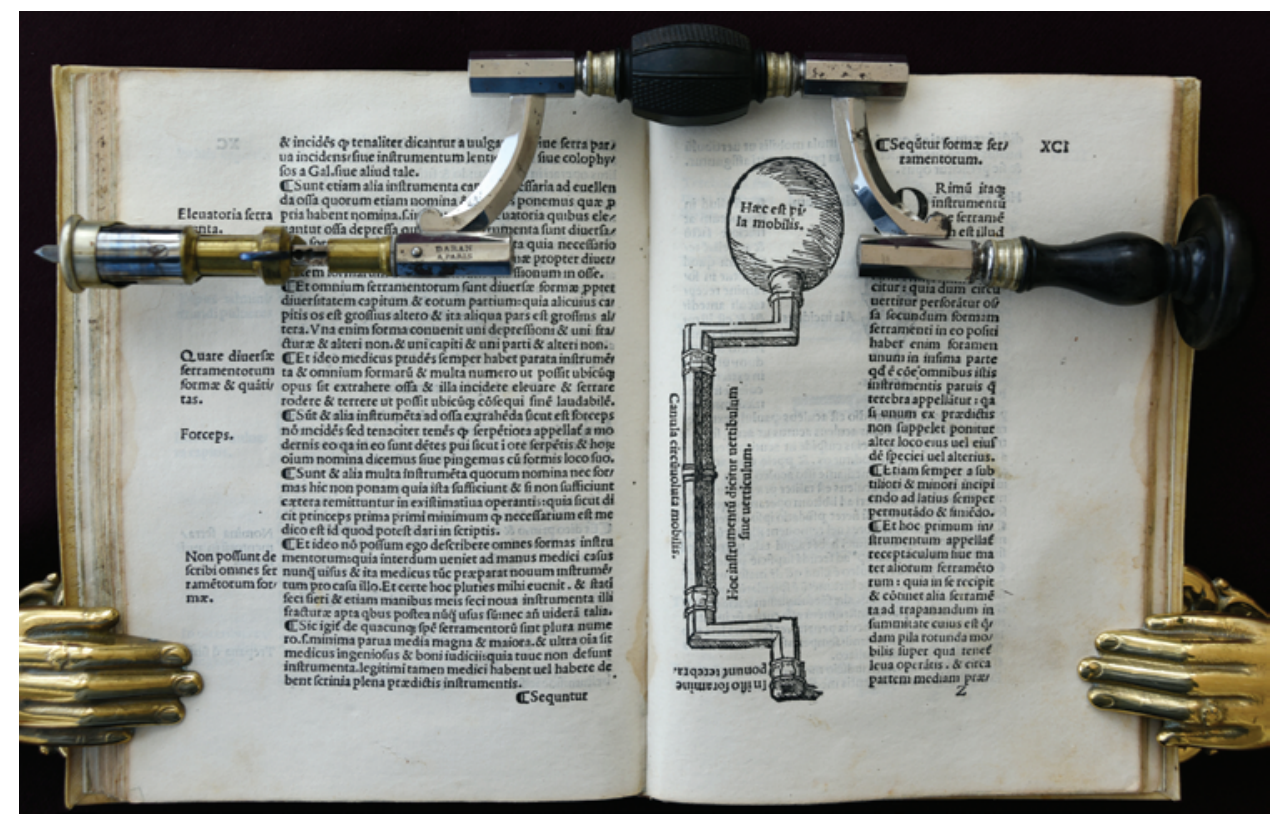

FIG. 9. A page from Berengario's Tractatus showing his original design of a trephine brace, what we now call a Hudson brace. This surgical innovation was introduced in the early 16th century and remains widely used today. Shown on top of the book is a French trephine brace from the late 18th century, which has a style and mechanism similar to that of Berengario's surgical piece from some 300 years later. Original source: Berengario da Carpi J: Tractatus de fractura calve sive cranei. Bologna: Hieronymus de Benedictis, 1518.

based on Berengario's own surgical (neurosurgical) experience, and his clinical observations reveal a very skilled and talented surgeon, though quite monomaniacal in writing style. In the book are some of the earliest illustrations of instruments designed to do a craniotomy. Berengario designed a "Hudson brace"-style trephine, a neurosurgical device still in use today. Berengario called this instrument a "vestibulum" and it had a rotating handle for ease of turning. He also designed a series of interchangeable burs that he called "terebra," which are quite remarkable both for their designs and the numbers that he provided. The drilling ends of the burs were tapered to prevent plunging into the brain. Berengario also designed a number of different shapes and styles of burs so that the surgeon had a number of options for how to make a bur hole or trephination. Along with his surgical treatments and techniques, Berengario also provided an elaborate description of his postsurgical care in which he noted the patient required several things for a good recovery. The patient needed to be kept comfortable with the wound cleaned and well dressed. Berengario often used wine as part of the wound care and dressing, an interesting observation as wine would also help in antisepsis.

Berengario's book described a number of interesting clinical cases that include both a subdural hematoma and an epidural hematoma plus a description of a contrecoup trauma injury. Berengario also provided an interesting case of what is likely a subdural empyema. Berengario was clearly an astute diagnostician who pointed out a number of clinical findings that can occur from a cranial lesion, which are important to note, as some of these findings are reported here for the first time. Berengario's findings included descriptions of signs of concussion, including bil- ious vomiting, loss of speech, and anisocoria (the last he notes is usually fatal), along with vertigo, falling down, and "stupor of the mind." Berengario poignantly added that ". . .once the patient is dead no assistance will be of value." A statement was made by Berengario in which he commented that "a physician is not a carpenter but works with the human body, he does not work with stone or leather."(Fig. 9-10).4,11,19

Berengario's studies added a good deal to the anatomical literature in that these observations were important to early brain anatomy. Berengario provided one of the earliest descriptions of the corpus striatum, pituitary, and pineal gland. A popular anatomical error held over from Galen's humoral theories was the anatomical structure called the rete mirabile..$^{20}$ Anatomically, this structure is seen only in ungulates and never in humans. After performing many careful anatomical dissections of human cadavers, Berengario dared to challenge the existence of this structure in humans. In a rather strong dialogue on human anatomy Berengario went on to state that this structure is an error of Galen and it clearly does not exist in humans. Considering the era, the then-present state of anatomy, and the practice, only an individual with a strong and unfortunately clearly a violent personality would dare to make such anatomical challenges; in the end he did, and he was right (Fig. 11).

In reviewing Berengario's lifestyle he clearly thrived in an arena of acrimonious behavior and despite this behavior was able to avoid incarceration on what appear to be numerous occasions due to his close relationships with royal families. In reflecting back on this surgeon's remarkable career, one would say this is clearly fortuitous for us historically, because without these connections, it is very unlikely that these remarkable works on anatomy and head 


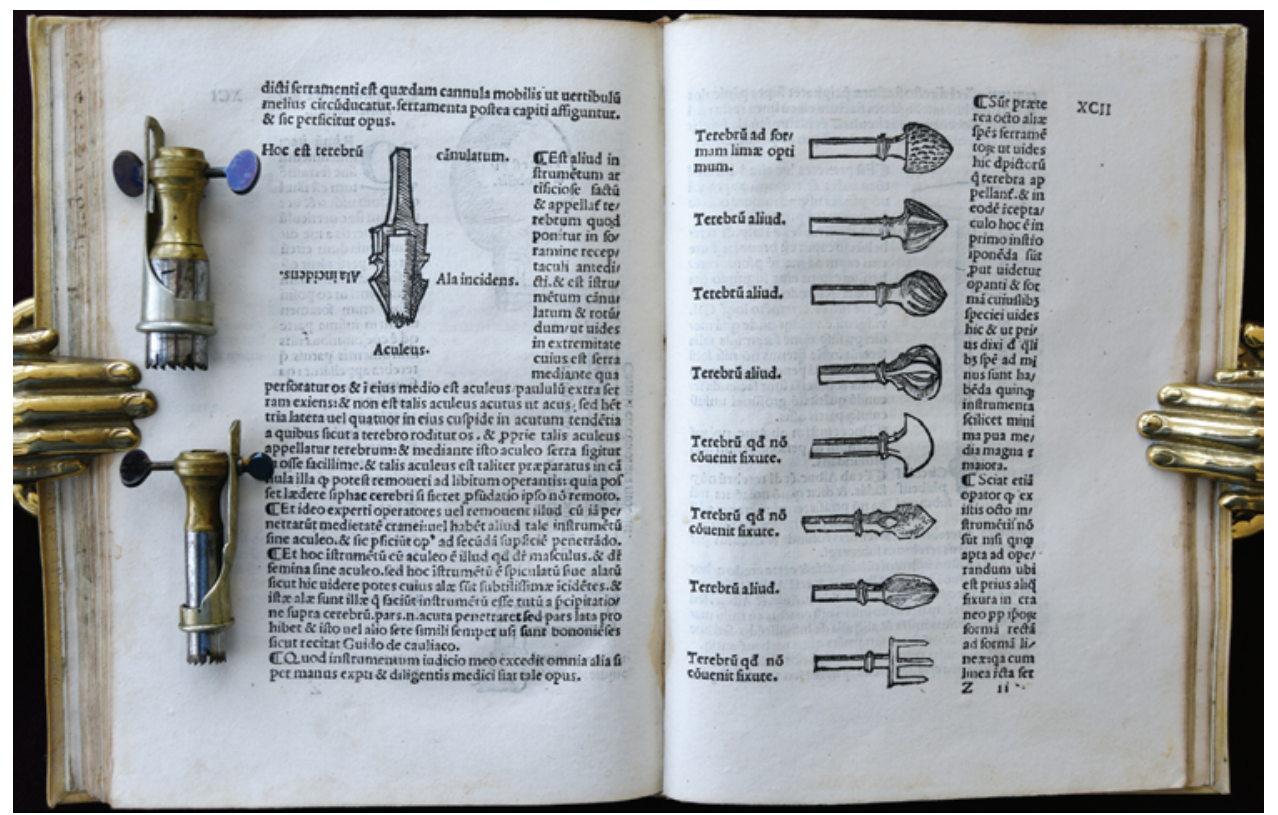

FIG. 10. Illustrations showing the ingenuity of Berengario's designs for various trephine burs. From conical to scalloped to Neptune designs, many remain popular today. Two interchangeable burs with depth gauges and centerpins that date from the early 19th century are shown on top of the left page. Original source: Berengario da Carpi J: Tractatus de fractura calve sive cranei. Bologna: Hieronymus de Benedictis, 1518.

injuries would have been produced (William A. Seaman, personal communication).

\section{Ambroise Paré and Henry II of France: 16th Century Death From a Jousting Injury to the Orbit With Entry Into the Brain}

Another prominent traumatic brain injury that occurred in the 16th century involved King Henry II (1519-1559) from the Royal Court of France. Henry's surgeon in consultation was Ambroise Paré (1510-1590), now considered the father of French surgery. Ambroise Paré's training in surgery was quite different from that of Berengario da Carpi. Paré underwent an apprenticeship as a barber-surgeon with no formal university education. Paré is described as having been an extremely intelligent surgeon with superb surgical dexterity and a personality that was both pleasant and charming.

Paré was able to take advantage of the extensive military and civil wars going on in Europe at the time to refine and hone his skills in surgery. Paré had a particular interest in head injuries, and, despite a lack of a formal medical education, was clearly familiar with the early writings of Galen and Hippocrates, both of whom were extensively cited in his writings. ${ }^{15-18}$

Paré commented, "I desire not to arrogate to myself that I have read Galen either in Greek or Latin, for it did not please God to be so gracious in my youth it should be, either in the one tongue or in the other."'17

His surgical writings reveal that he was clearly an expert at trephination and also an expert at dealing with skull fractures. Due to the nature of war injuries, surgery on the skull and brain were quite common in any surgical prac-

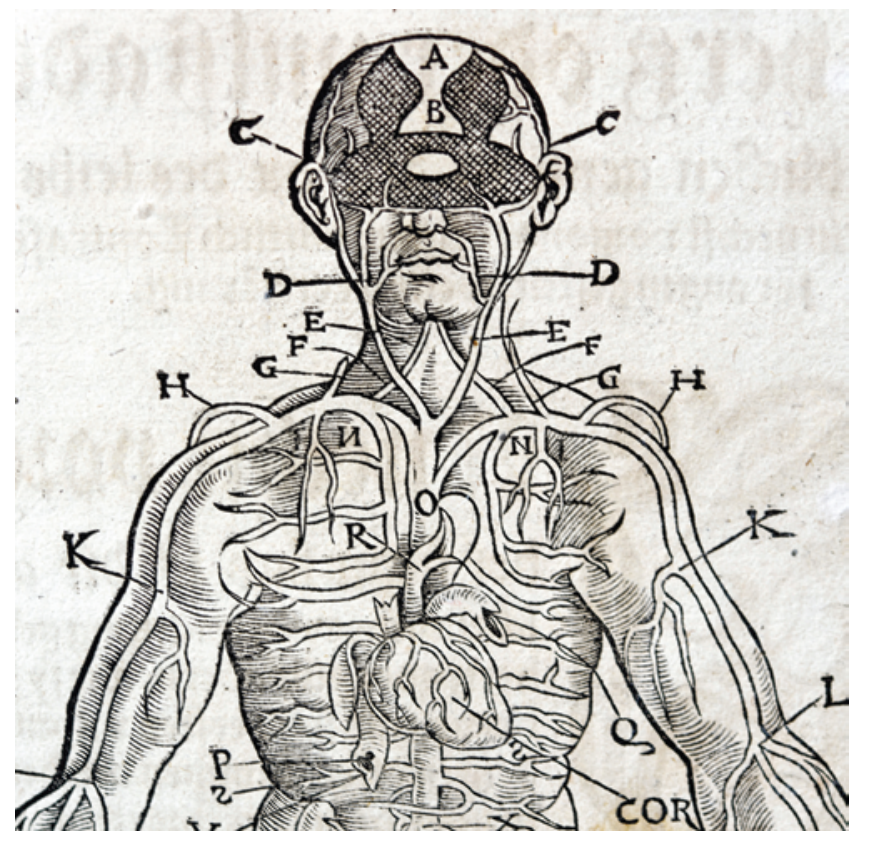

FIG. 11. In the 2nd century AD, Galen of Pergamon introduced the concept of humoral therapy and the various "humors" that circulated through the body. Part of the theory included the rete mirabile that was introduced into human anatomy from dissections done on ungulates. The rete was believed to be an anastomotic network at the base of the brain. The humoral theory and anatomy of the rete mirabile became very pervasive and in turn became ex cathedra doctrine in anatomical teachings for the next 1300 years. Based on his anatomical dissections, Berengario was the first to seriously question whether this structure truly existed in humans. An example the rete mirabile is illustrated here in this anatomy work by Ryff, a contemporary anatomist of this era. Original source: Ryff WH: Des aller fürtrefflichsten, höchsten vnnd adelichsten geschöpffs aller Creaturen. Strassburg: Balthassar Beck, 1541. 


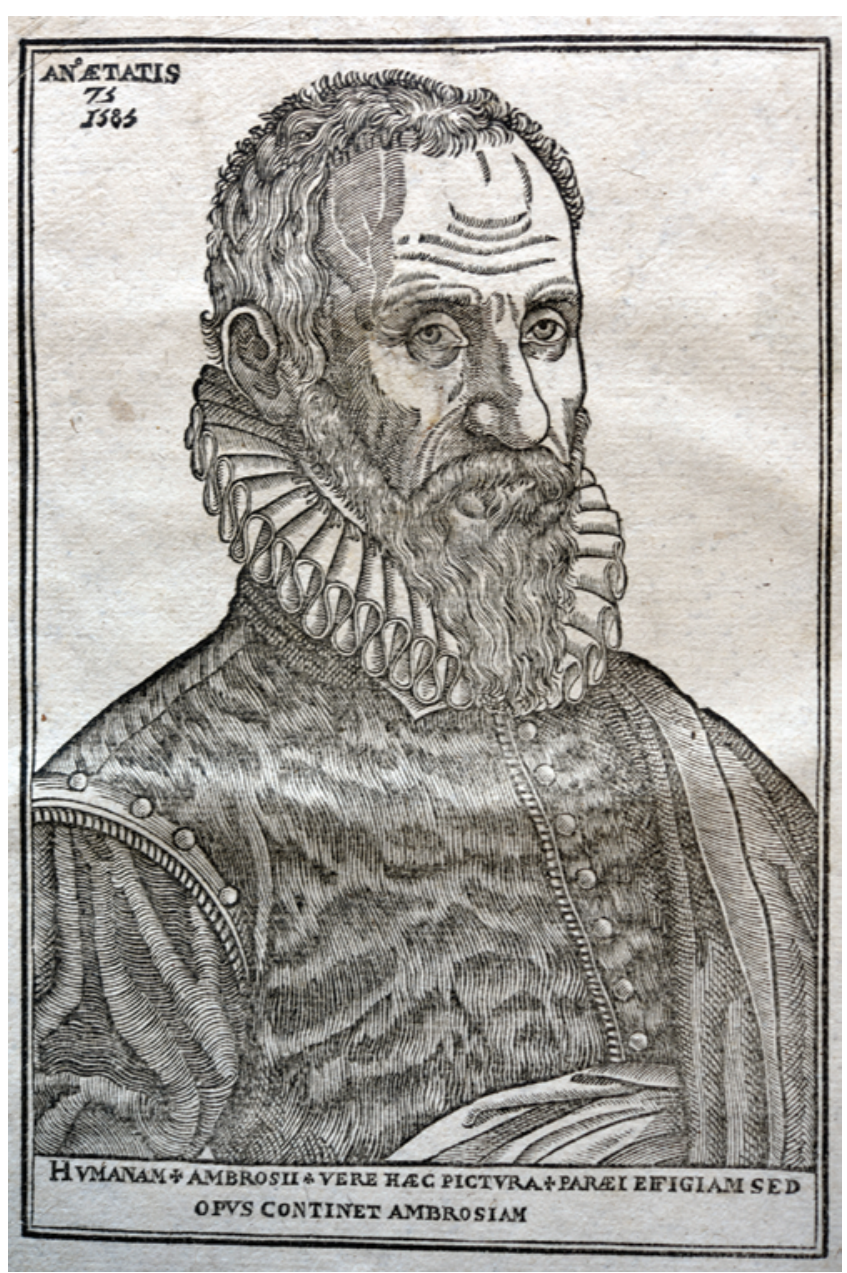

FIG. 12. A portrait engraving of Paré that appeared in his collected works published in 1633. Original source: Paré A: Les Oeuvres d'Ambroise Pare. Lyon: Rigaud et Obert, 1633.

tice. In reviewing Paré's writing, it is evident that he often dealt with evacuation of blood clots, elevation of skull fractures, abscesses, and the like. So prominent did his career become that he was asked to be court surgeon by a number of royalty, including the French monarchs Francis II, Charles IX, Henry II, and Henry III (Fig. 12).

Paré originally apprenticed himself to his older brother and later studied at the Hotel Dieu in Paris, France. He published a landmark work in 1545 on the method of curing wounds caused by "arquebus and firearms." 15 It was the introduction of gunpowder and more powerful weapons that clearly upped the ante in head injury at this time. Paré clearly did not like the use of gunpowder and "fiery engines," leading him to write of his dismay on the use of gunpowder and warfare in a chapter entitled "Of wounds made by Gvnshot, other Fierie engeines, and all sorts of weapons": 17

I have thought good here to premise only opinion of the originall, encrease, and hurt of fiery Engines, for that, I hope it will be an ornament and grace to this my whole treatise: as also to intice my Readers, as it were with these junckets, to our following Banquet so much flavorring of Gunpowder. For thus it

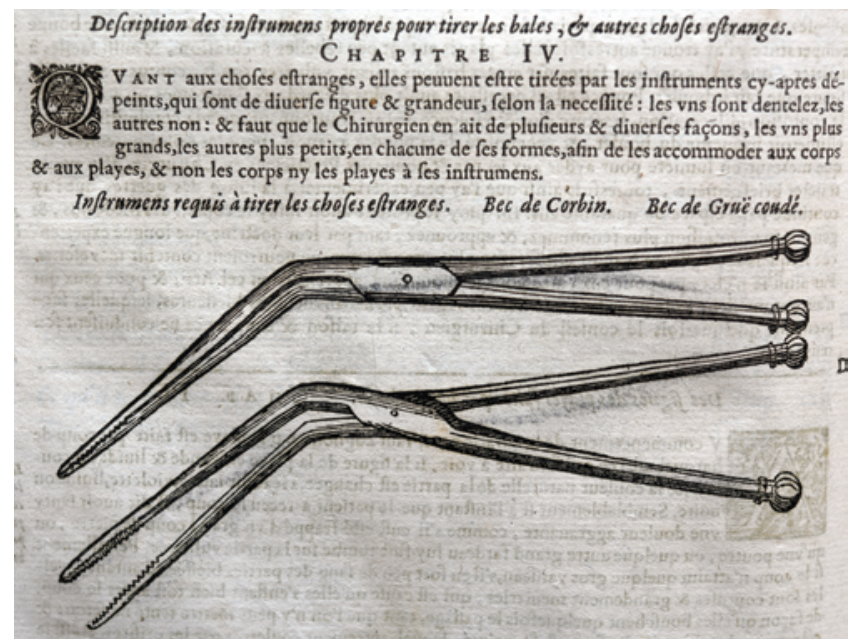

FIG. 13. A historically important instrument designed by Paré that he called the "Bec de Corbin" (crow's beak). Pare designed this instrument as a clamp that could be applied to a bleeding vessel to reduce blood loss. This technique replaced a more common treatment, which was the use of a hot cautery iron placed on the vessel. Original source: Paré A: The Works of that Famous Chirurgion Ambrose Parey. Translated out of Latine and compared with the French. by Tho: Johnson. London: Cotes and Young, 1634.

shall bee knowne to all whence Guns had their originall, and how many habits and shapes they have acquired from poore and obscure beginnings, and lastly how hurtfull to mankind the use of them is. ${ }^{17}$

A commonly used 16th century treatment for gunshot wounds and similar injuries was the pouring of hot oil (elderberry oil) into the wounds, a technique originally introduce by Giovanni de Vigo (1460?-1535?). This treatment, along with scalding oil, helped to fight against any "poisons" being introduced into the wound by gunpowder and thereby provided a better outcome. Paré used this treatment as his standard, but during the Battle of Piedmont (1536-1538), Paré ran out of oil because of the numerous battle injuries. He switched over to simply placing a wound dressing. He added to the dressing another medical remedy that he devised, which was composed of oil of roses, egg white, and turpentine. In retrospect, the key to this recipe was the turpentine as it provided an unappreciated antiseptic quality to the healing. Paré was impressed when he found that these patients fared much better in both the healing of wounds and outcome.

Paré described his observations in a chapter entitled, "The First discovrse VVherin Wounds made by Gvnshot, are freed from being Bvrnt, or cavterized According to Vigoes Method": 17

In the yeare of Our Lord 1536 . . I was in the King's Army of Monsieur Moniegan [i.e., Mareschal de Montjean] . . . In this conflict there were many wounds on both sides with all sorts of weapons but chiefly with bullets. I will tell the truth, I was not very expert at the time in matters of chirurgery; neither was I used to dress wounds made by gunshot. Now I had read John de Vigo that wounds by gunshot were venerate or poisoned, and that by reason of the Gunpowders; wherefore for the cure, it was expedient to burne and cauterize them with the Oyle of Elders scalding hot, with a little treacle mixed there with. ${ }^{17}$ 


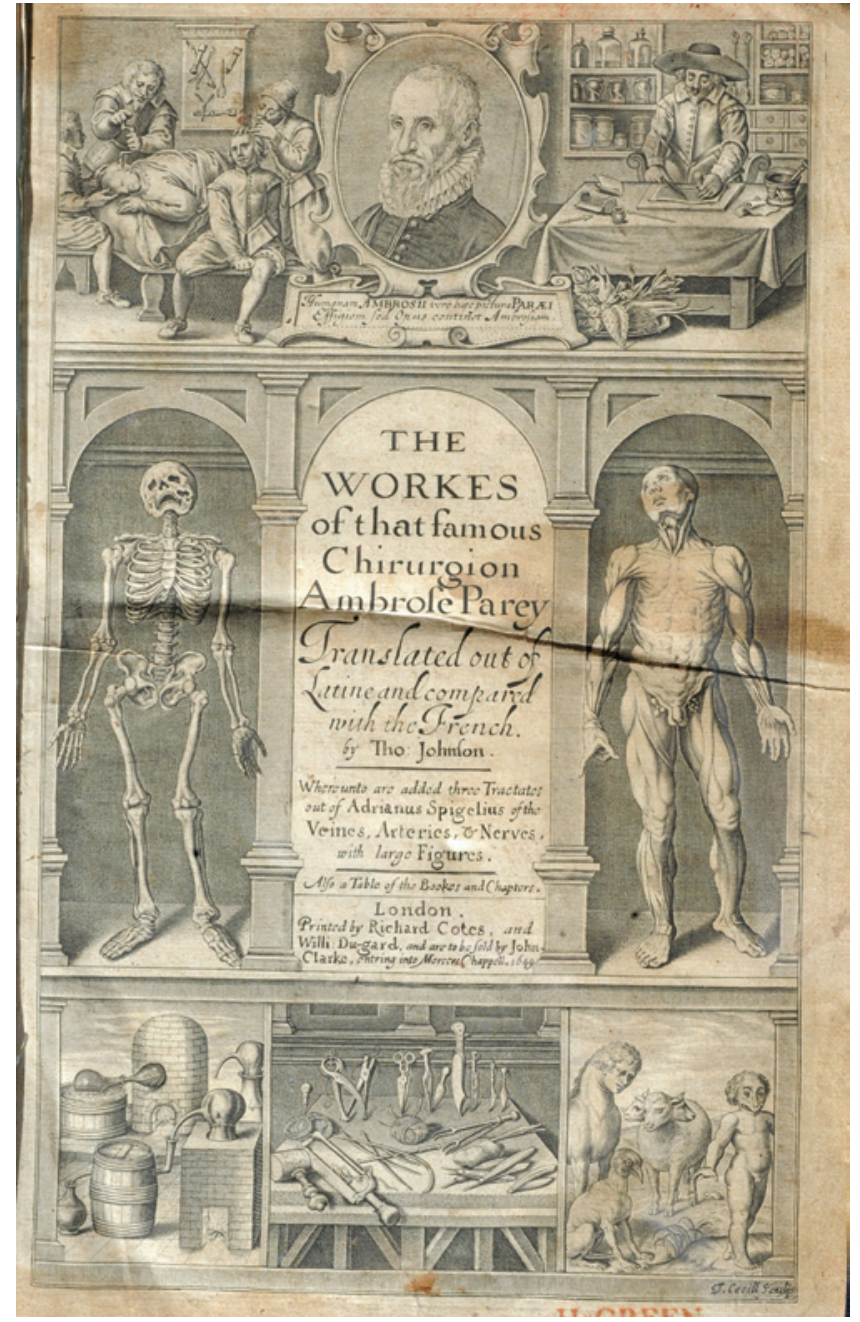

FIG. 14. Title page from an English edition of Paré's surgical works. In the upper left corner is an illustration of trephination being performed in the home of the patient. A portrait of Pare is seen in the upper middle panel. Original source: Paré A: The Works of that Famous Chirurgion Ambrose Parey. Translated out of Latine and compared with the French. by Tho: Johnson. London: Cotes and Young, 1634.

Paré went on to note that this was the typical practice by other surgeons. However, due to the extensive number of men injured on the battlefield, he ran out of oil. As a result, he was forced to devise his new treatment of placing a dressing soaked in elderberry oil and turpentine. He noted, "I could not sleepe all that night, for I was of troubled in minde ... I feared that the next day I would find them dead" (i.e., due to the poison from the gunpowder). To his amazement, he found his patients awake, eating, and in much less pain; moreover, the wounds were neither inflamed nor swollen. Those soldiers who had been treated with the burning oil were feverish and tormented with much pain, and parts of their wounds were swollen.

It is from this war that Paré came up with the oftenquoted phrase, "Je le pansai, Dieu le guérit" (I bandaged him and God healed him). Another change in his surgical practice occurred when he switched from using hot cautery to sear and burn a bleeding artery to the placement of

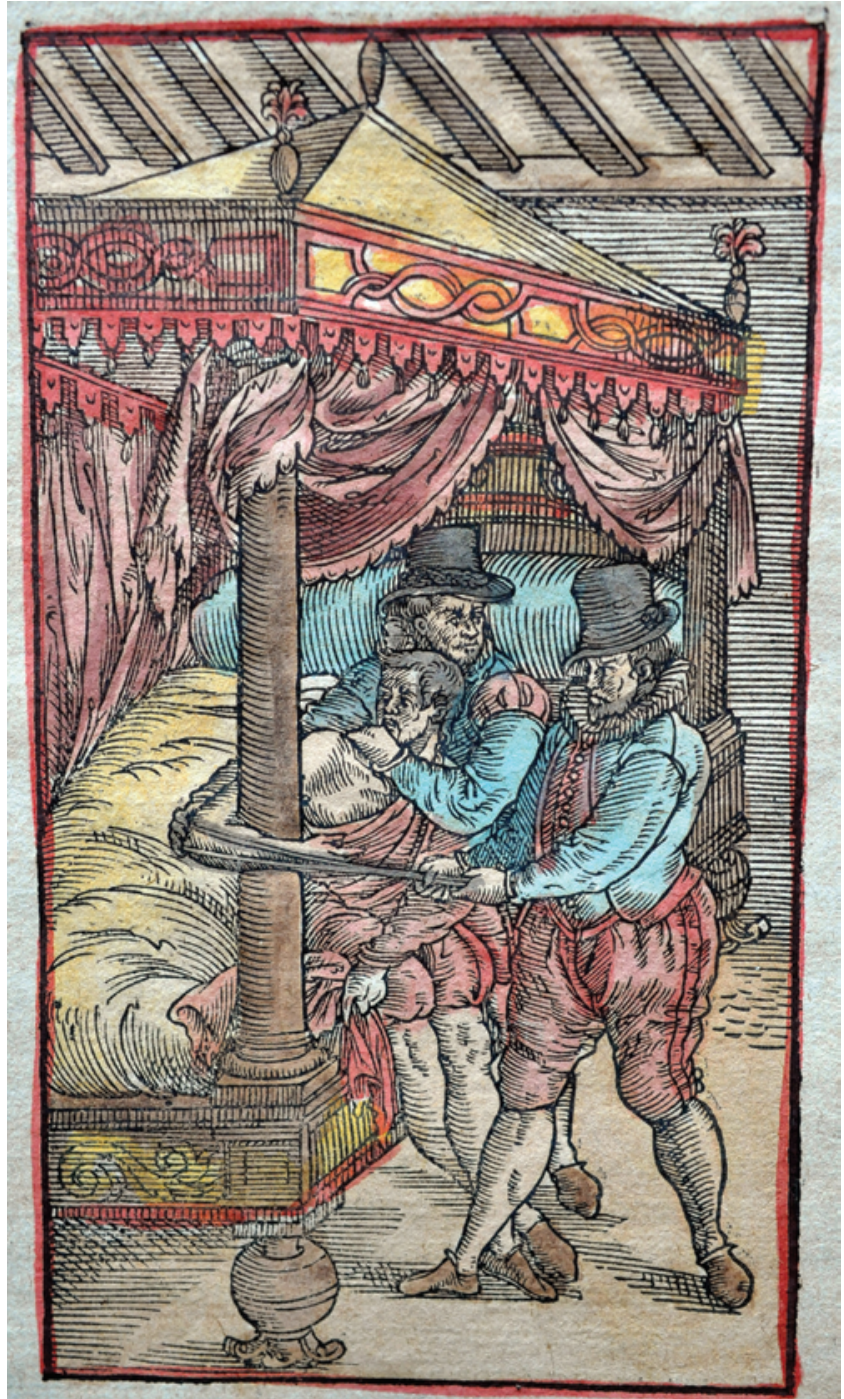

FIG. 15. A typical surgical scene showing an operating room from the 16 th century. In this case Paré has traveled to a noble's home and in the bedroom he can be seen setting a fracture or possible dislocated shoulder using a bedpost and brute strength with no anesthesia. Original source: Paré A: The Works of that Famous Chirurgion Ambrose Parey. Translated out of Latine and compared with the French. by Tho: Johnson. London: Cotes and Young, 1634.

a ligature and the use of the "Bec de Corbin" (crows beak), an instrument similar to what we now call a hemostat. By good fortune these results only enhanced Parés reputation, and as a result he came to be rapidly recognized by the royal families, especially those of France (Fig. 13).

Paré became associated with the Valois dynasty through Henry II (1519-1559) who had married Catherine de Medici (1518-1589) in 1533. Catherine was only 14 years of age. As was common for the period, Henry would come to have multiple mistresses and a love of hunting and jousting. The fateful traumatic event that ended his life occurred during a jousting tournament on June 30, 1559. The tournament was part of a series of events that were set up to celebrate the upcoming wedding of Henry's daughter Elizabeth to Philip II. Henry II was also cele- 


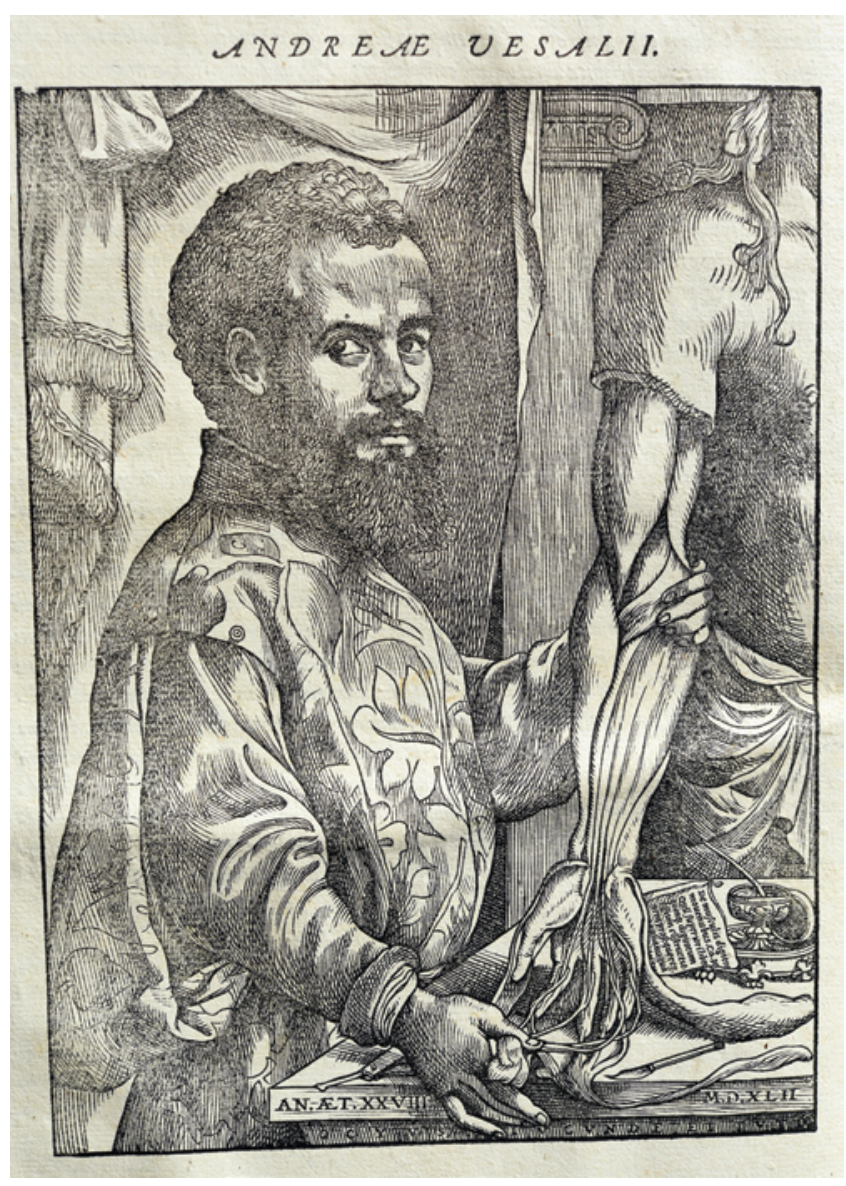

FIG. 16. Engraved portrait of Vesalius taken from his magnum opus published in 1543. Original source: de Vigo G: Practica in arte chirurgica copiosa...continens novem libros. Rome: S Guillitreti et H. Bononiensem, 1514. brating a recently signed peace treaty, the Peace of Cateau Cambrésis. The celebration included eating, drinking, and jousting. A jousting event required two mounted warriors encased in armor suits to ride atop horses while holding long, pointed wooden spears; the winner was the one still left on the horse. Henry's jousting partner was Gabriel, comte de Montgomery (1530-1574), Captain of Henry's Scots Guard, who had already unseated Henry earlier in the day at another jousting event. Henry's wife Catherine felt he was too tired to perform in the tournament but Henry felt otherwise and proceeded with the joust. This event was foreshadowed by Michel de Nostradamus (1503-1566). Nostradamus was a French physician, astrologer, and occultist educated in medicine at Montepellier. His reputation as a physician developed from his treatment of plague victims in his town of Alx, France. Later in his career he became a writer of quatrains, short 4-line, prophetic, and often enigmatic verses written during periods of solitude and personal reflection. It appears that Nostradamus was more often than not correct in his prophecies. In a famous quatrain, he noted that Henry should not engage in either combat or a joust:

The Lion shall overcome the old on the field of war in a single combat (duele);

He will pierce the eyes in a cage of gold.

This is the first of two lappings, then he dies a cruel death. ${ }^{12}$

Catherine de Medici added Nostradamus to her court after this prophesy (Figs. 14-18). ${ }^{7}$ This prophesy turned out to be true as Henry was to be later mortally wounded. During a jousting event, Henry's opponent managed to pass his jousting spear through the opening in his armored visor where it entered the right orbit. There has been much controversy about Henry and the visor on his suit of ar-

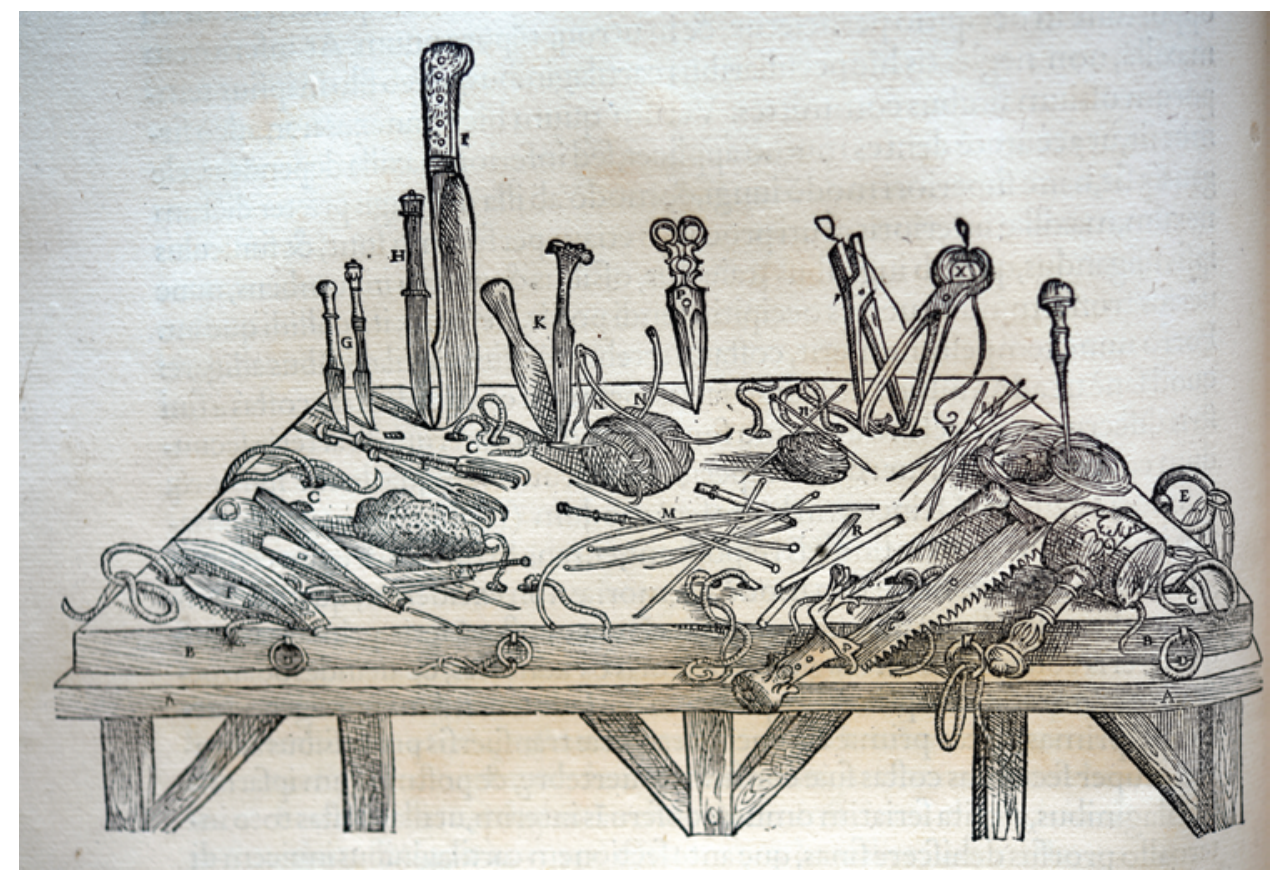

FIG. 17. A table of instruments that Vesalius would use for both anatomical dissections and surgeries. Original source: de Vigo G: Practica in arte chirurgica copiosa...continens novem libros. Rome: S Guillitreti et H Bononiensem, 1514. 


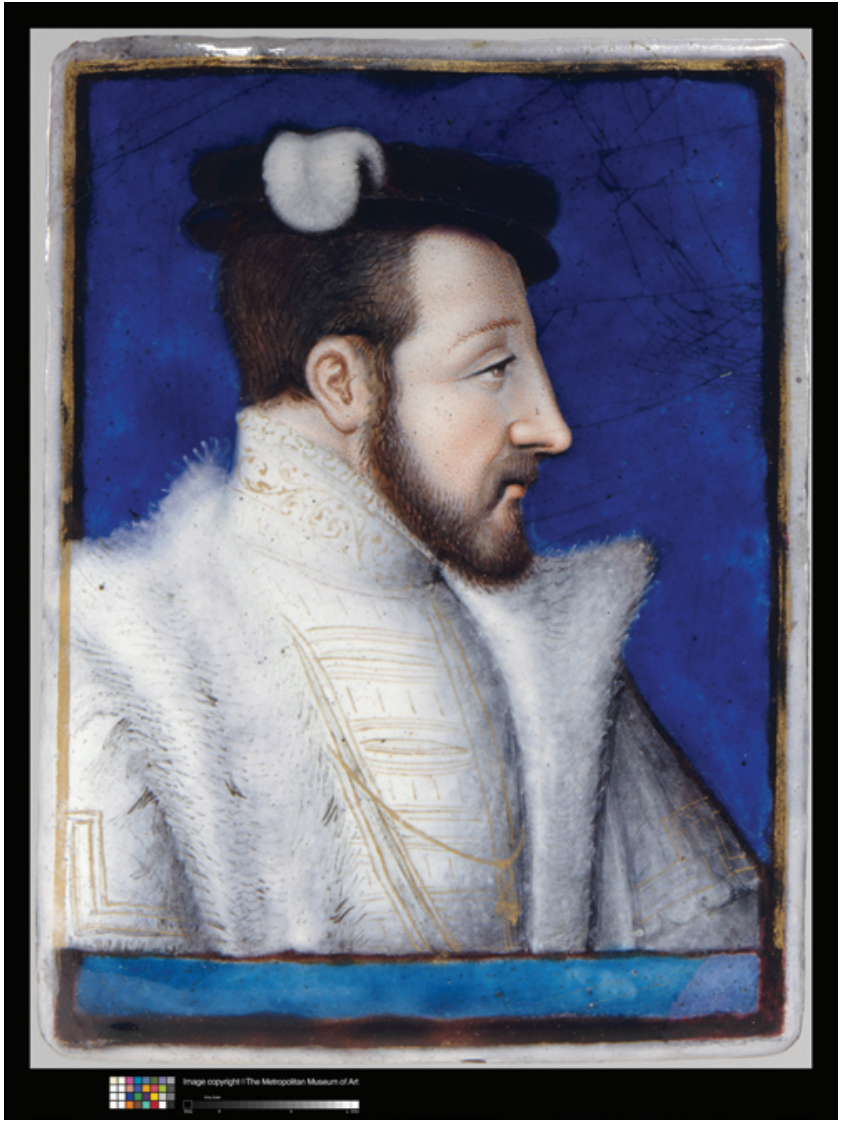

FIG. 18. An oil portrait of Henry II. Image copyright @ The Metropolitan Museum of Art. Image Source: Image Resource, NY.

mor. It would appear that he rode with his protective visor poorly secured or up over the forehead. The lance entered the right orbit and blinded the eye. Witnesses reported that he remained conscious and was able to dismount the horse, albeit with profuse bleeding from the orbit. He was able to walk up some steps with an unsteady gait. He then collapsed and become obtunded. Montgomery was so devastated by the injury he asked the king to remove his head and hand, which Henry refused to do. He is said to have absolved the count on his deathbed. The local physicians were reported to have removed some of the wood splinters from the king's eye plus several others from his face and throat. As was common practice at the time the King was bled from a vein. Recognizing the severity of the injury, Philip II ordered Andreas Vesalius (1514-1564) to come from Belgium to attend to his father. Vesalius was a prominent Flemish anatomist and surgeon, whose birth anniversary of 500 years was celebrated in 2014. Henry's family requested that Ambriose Paré come and also provide care. Vesalius arrived on July 3, 1559. He performed a crude neck maneuver, which elicited signs of meningismus. Based on this finding Vesalius felt that Henry had no chance to survive. He used the phrase chironim vulnus: the wound will not heal. ${ }^{22} \mathrm{He}$ discussed possible trephination of the injury but in the end rejected the treatment. On the 4th day postinjury, the king developed a fever. He later suffered from paralysis of his left arm and leg along

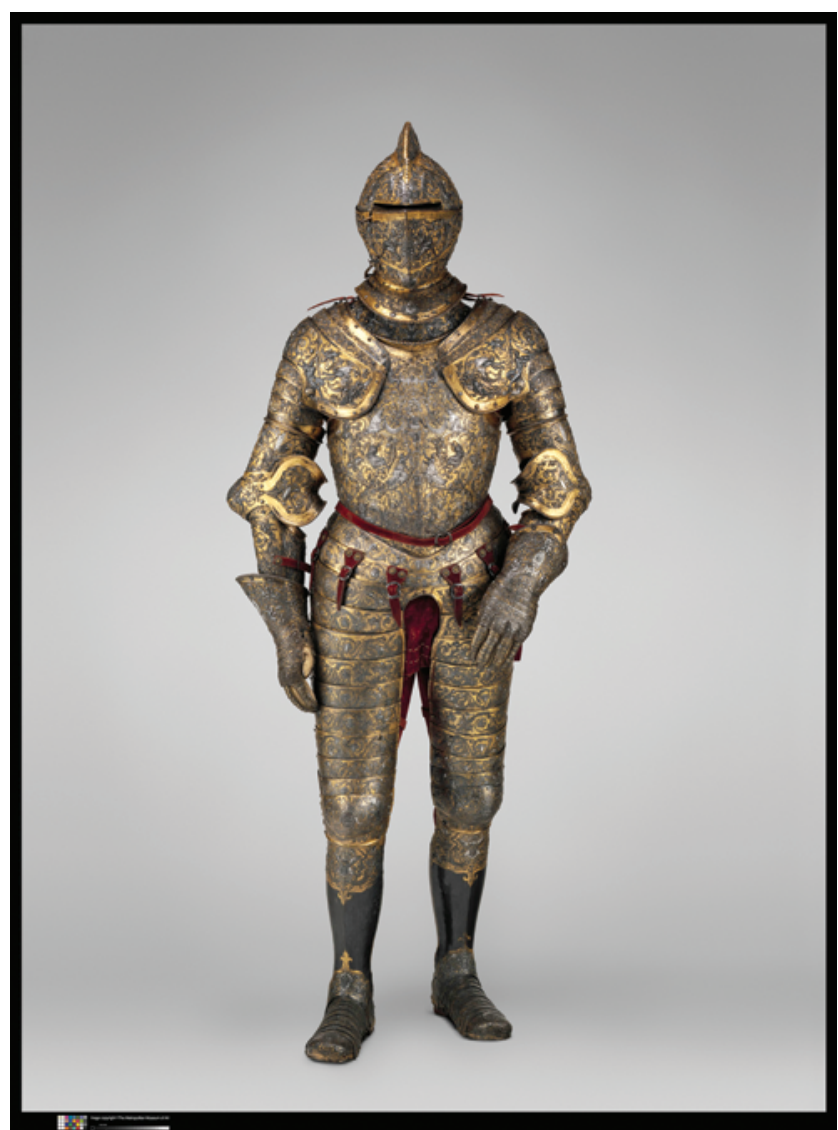

FIG. 19. The armor suit belonging to Henry II that is now part of the collection of the Metropolitan Museum of New York. This was a special presentation armor suit to Henry II and is quite ornate in detail. Image copyright (C) The Metropolitan Museum of Art. Image Source: Image Resource, NY.

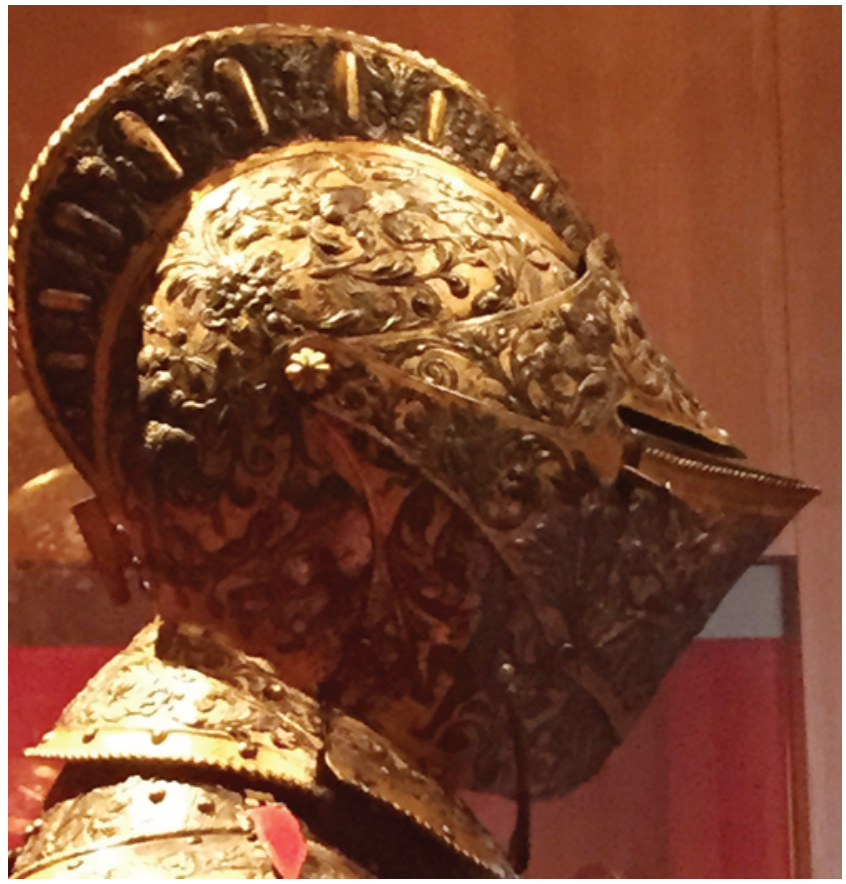

FIG. 20. A side view profile shot of the armor suit visor. Image taken by author (K.A.D.). 


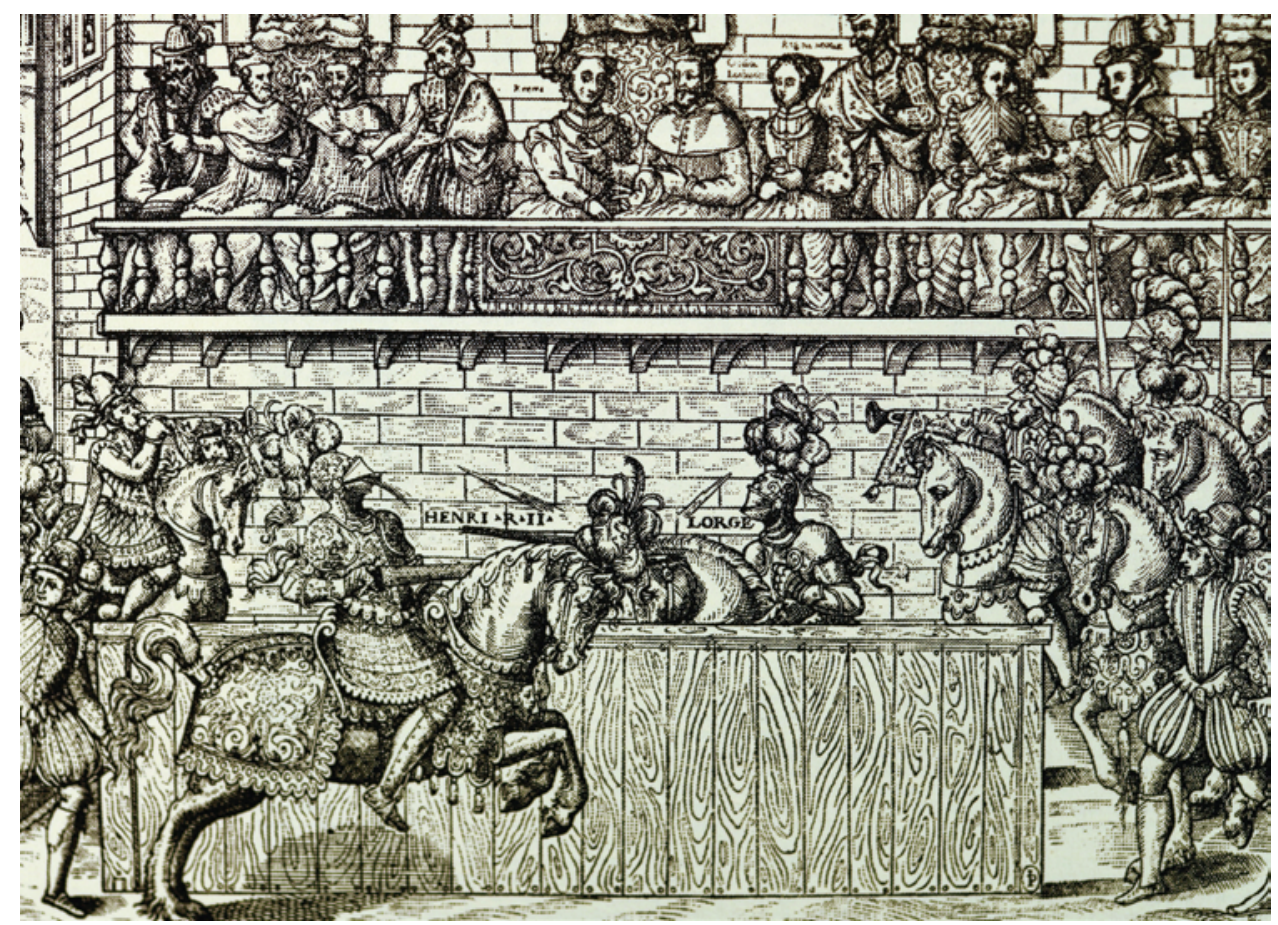

FIG. 21. An engraving dating from the 16th century (ca. 1560) showing the jousting event between Henry II and the Count of Montgomery-this scene shows the moment of impact of Montgomery's lance hitting the chest plate of Henry II and a fragment splintering upward and entering the orbit of Henry II. There is also a large fragment of the jousting lance flying off to one side just above the "Henry R II." Image from the collection of the author (J.T.G).

with grand mal seizures. Toward the end of his illness, he developed very labored (likely agonal) respirations with death occurring 11 days postinjury on July 10, 1559 (Figs. 19 and 20). ${ }^{13,22}$

Paré also wrote of his observations of Henry II's injury.

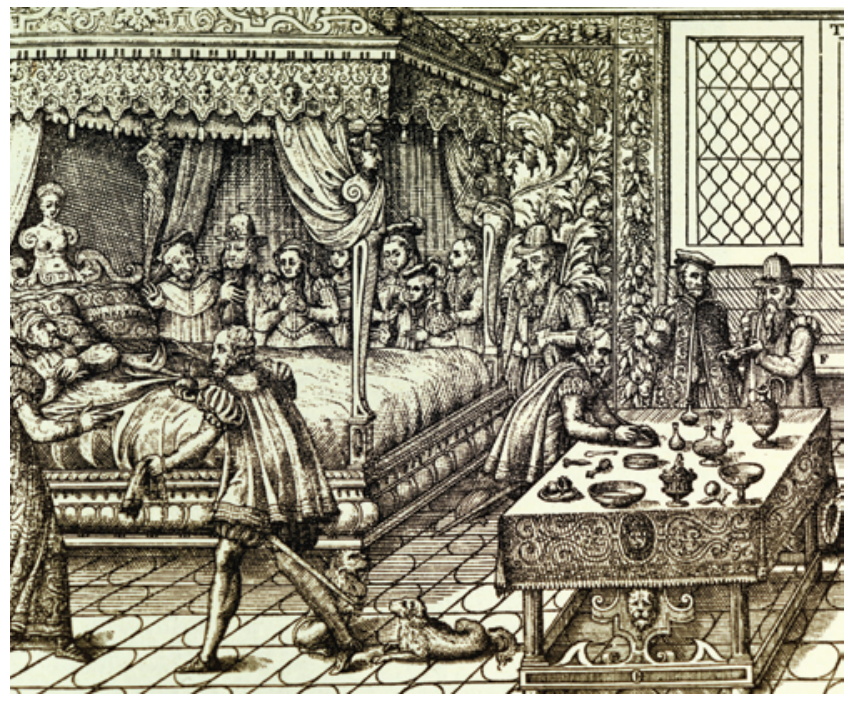

FIG. 22. An engraved scene dating from the 16th century depicting the bedroom of Henry II with Ambroise Paré and Andreas Vesalius in attendance. Henry can be seen resting in his canopied bed surrounded by a group of anxious servants and maidens plus his mistresses. Image from the collection of the author (J.T.G.).
In a section on head injuries, Paré used this case as an argument on when to trephine and when to not. He began the paragraph with comment of a "happy memory" of Henry II. He noted that Henry II was involved in a "tilting" (jousting) tournament during which he was hit in the breast plate. Pare described the following:

". . . that with the violence of the blow, the visour of his helment flew up, and the truncheon of the broken lance, hit him about the left eye-brow (the side is in error as the injury occurred to the right orbit - author comment), and the musculous skinne of the fore-head was torne even to the lesser corner of the left eye, many splinters of the same truncheon being struck into the substances of the fore mentioned eye, the bones being not touched or broken, but the braine was so moved and shakened that he died the eleventh day after the hurt."17

Paré also described his observations at the autopsy in which was noted a subdural hematoma plus "...the substance of the braine was corrupted" (Figs. 21 and 22).

As reported by Paré, an autopsy was later performed on Henry. Adding to the details reported by Paré, a disrupted right orbit with multiple wood splinters from the jousting lance was found. Interestingly, there appeared to be no injury to the dura mater or brain. At the vertex of the brain Paré and his observers found "two thumbs" (size) of yellowish brain filled with serous "ichor-like" fluid, likely some sort of gangrene. A subdural collection of "grumous" blood was present and also reported. They concluded that this was a severe concussion-type injury with an associated contrecoup injury. With the wood splinters penetrating the orbit infection was carried up into the brain, forming 


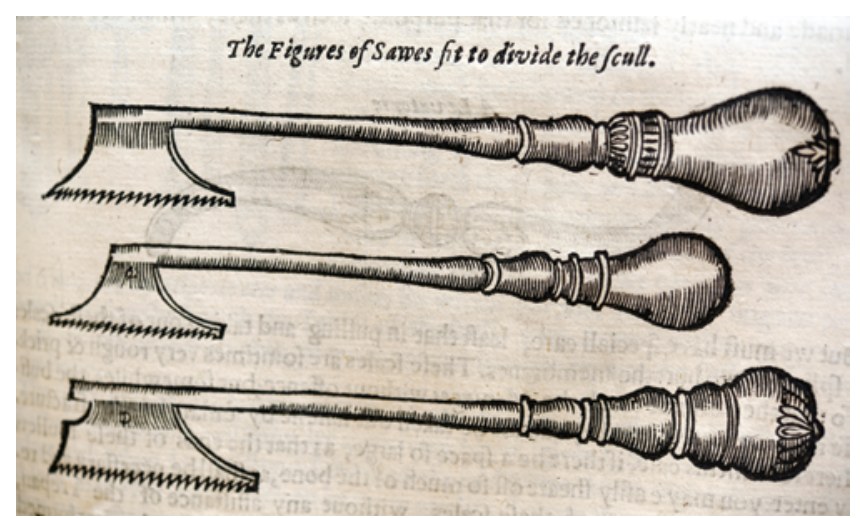

FIG. 23. From Paré's work showing an instrument that he would use to make a trephination. This saw type would remain popular until well into the 19th century when it became referred to as a Hey saw, of which many designs were available. Original source: Paré A: The Works of that Famous Chirurgion Ambrose Parey. Translated out of Latine and compared with the French. by Tho: Johnson. London: Cotes and Young, 1634.

eventually a large cerebral abscess and subdural empyema (Figs. 23 and 24).

The story, however, does not end here. The Code of Hammurabi and its laws, which date to prebiblical times (ca. $1750 \mathrm{BC}$ ), were to come into effect. One of the concepts of this code dealt with the vengeance of an "eye for an eye" and a "tooth for a tooth," meaning that a person could take revenge for a perceived offense. Surgeons and physicians lived in fear of these codes as failure in the care of a patient could lead to the loss of a hand or even death in severe injuries if they were attributed to the care of the provider. In this case, neither Vesalius nor Paré came to harm; however, the same cannot be said for Gabriel, comte de Montgomery. Catherine subsequently beheaded the count in 1574. In addition to his perceived care of Henry II, Montgomery went on to convert religions from Catholic to Protestantism, making him an enemy of the government. However, Catherine's violent acts did not begin here. When her husband was being treated, Catherine had 4 criminals beheaded and ordered broken wood lances be thrust into the orbits of the corpses to determine the angle and location of penetration. This was done in the hopes of finding a surgical cure for her husband's injury.

The death of King Henry II would cause further significant instability within the various European powers. His death allowed further destructive religious wars plus a good deal of internal strife in France. Spain, in particular, would be allowed to develop further power up until the launch of the "Great Armada" (1588) against England. England ended up defeating the Armada and thereby knocking Spain out of the top level of European powers and thereby again changing both religious and economic impacts for Europe. Paré would go on to die a very wealthy man at the age of 80 years. Due to some "anatomic" misdeeds, Vesalius was ordered to undergo a penitent pilgrimage to the Holy Land (Jerusalem). On his return home he was at sea for several weeks without wind, only to finally land on the island of Zykanthos (Zante) off of Greece where historians believe he likely died of the scourges of scurvy.

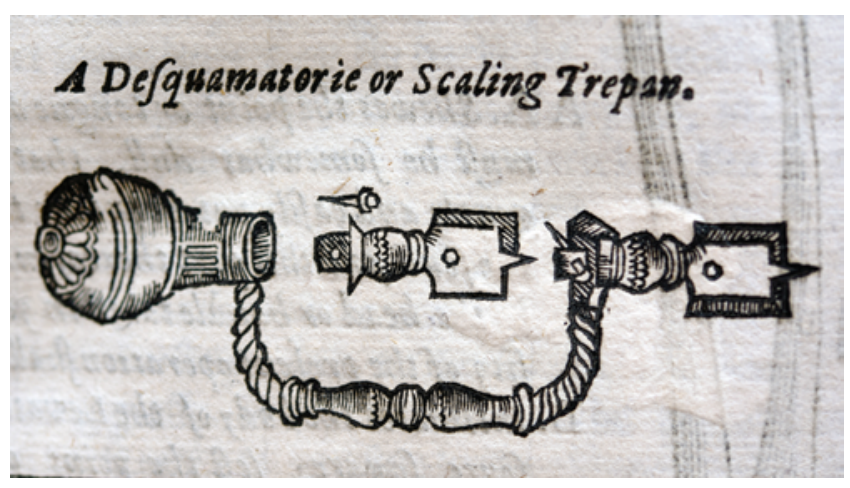

FIG. 24. The hand brace that Paré designed for performing a bur hole. The brace would accept different burs of various shapes and design. The style is similar to what Berengario had introduced earlier. Original source: Paré A: The Works of that Famous Chirurgion Ambrose Parey. Translated out of Latine and compared with the French. by Tho: Johnson. London: Cotes and Young, 1634.

\section{Conclusions}

We have presented 2 historical events in which surgeons were called in to treat serious cranial injuries at a time when neither antisepsis nor anesthesia was available. This was a time of royal, religious, and civil wars, which involved political and royal figures of historical significance. Equally so, the surgeons involved were also prominent figures who made significant contributions to the fields of medicine, anatomy, and surgery. A historical review of these surgeons' contributions to the care of these individuals is an important part of our neurosurgical history.

\section{References}

1. Berengario da Carpi J: Anothomia Mundini noviter impressa ac per Carpum castigata. Bononiae: H. de Benedicitum Hectoris, 1514

2. Berengario da Carpi J: Commentaria cum amplissimis additionibus super anatomia Mundini una cum textu ejusdem in pristinum et verum nitorem redato. Bononiae: H. de Benedictis, 1521

3. Berengario da Carpi J: Isagoge breves, perlucide ac uberime in anatomia humani corporis a communi medicorum academia usitatam. Bologna: Benedicitum Hectoris, 1522

4. Berengario da Carpi J: Tractatus de fractura calve sive cranei. Bologna: Hieronymus de Benedictis, 1518

5. Cavalcanti DD, Feindel W, Goodrich JT, Dagi TF, Prestigiacomo CJ, Preul MC: Anatomy, technology, art, and culture: toward a realistic perspective of the brain. Neurosurg Focus 27(3):E2, 2009

6. Cicero: De Re Publica. Zetzei JEG, ed. Cambridge: Cambridge University Press, 1995

7. de Vigo G: Practica in arte chirurgica copiosa...continens novem libros. Rome: S Guillitreti et $\mathrm{H}$ Bononiensem, 1514

8. Di Ieva A, Gaetani P, Matula C, Sherif C, Skopec M, Tschabitscher M: Berengario da Carpi: a pioneer in neurotraumatology. J Neurosurg 114:1461-1470, 2011

9. Faria MA Jr: The death of Henry II of France. J Neurosurg 77:964-969, 1992

10. Goodrich JT: Sixteenth-century Renaissance art and anatomy: Andreas Vesalius and his great book-a new view. Med Herit 1:280-288, 1985

11. Lind LR (trans): Berengario da Carpi: On Fracture of the 
Skull or Cranium. Philadelphia: American Philosophical Society, 1990, Vol 80, Part 4

12. Nostradamus M: Prophesies. New York: G.P. Putnam's Sons, 1980

13. O’Malley CD: Andreas Vesalius of Brussels 1514-1564. Berkeley: University of California Press, 1964

14. O’Malley CD: Berengario da Carpi, in Gillispie CC (ed): Dictionary of Scientific Biography. New York: Scribners, 1973, Vol 1, pp 617-621

15. Paré A: La Méthode de traicter les playes faictes par hacquebutes et aultres bastons à feu; et de celles qui sont faictes par flèctes, dardz et semiblables. Paris: Gaulterot, 1545

16. Paré A: Les Oeuvres d'Ambroise Pare. Lyon: Rigaud et Obert, 1633

17. Paré A: The Works of that Famous Chirurgion Ambrose Parey. Translated out of Latine and compared with the French by Tho: Johnson. London: Cotes and Young, 1634

18. Park R: Injuries and surgical diseases of the head, in Park R (ed): A Treatise on Surgery by American Authors, for Students and Practitioners of Surgery and Medicine, ed 3. New York: Lea Brothers, 1901

19. Putti V: Berengario da Carpi: Saggio biografico e bibliografico, seguito dalla traduzione del De Fractura Calvae Sive Cranei. Bologna: L Cappelli, 1937

20. Ryff WH: Des aller fürtrefflichsten, höchsten vnnd adelichsten geschöpffs aller Creaturen. Strassburg: Balthassar Beck, 1541

21. Vesalius A: De Humani Corporis Fabrica. Basel: Oporinus, 1543

22. Zanello M, Charlier P, Corns R, Devaux B, Berche P, Pallud $\mathrm{J}$ : The death of Henry II, King of France (1519-1559). From myth to medical and historical fact. Acta Neurochir (Wien) 157:145-149, 2015

\section{Disclosures}

The authors report no conflict of interest concerning the materials or methods used in this study or the findings specified in this paper.

\section{Author Contributions}

Conception and design: Goodrich. Acquisition of data: both authors. Drafting the article: both authors. Critically revising the article: Dowling. Reviewed submitted version of manuscript: both authors.

\section{Correspondence}

Kamilah Dowling, Division of Pediatric Neurosurgery, Children's Hospital at Montefiore, 111 East 210th St., Bronx, NY 10467. email: kdowling@montefiore.org. 